\title{
PERAN BANK INDONESIA DALAM MENJAGA STABILITAS SISTEM KEUANGAN DI TENGAH PANDEMI COVID 19
}

\author{
Meutia Handayania ${ }^{*}$, Talbani Farliani ${ }^{\mathrm{b}}$, Riski Fandika ${ }^{\mathrm{c}}$, Indah Islami ${ }^{\mathrm{d}}$ \\ a, Politeknik Aceh - Banada Aceh \\ ${ }^{\mathrm{b}, \mathrm{c}, \mathrm{d}}$ Fakultas Ekonomi Dan Bisnis , Universitas Syiah Kuala-Banda Aceh

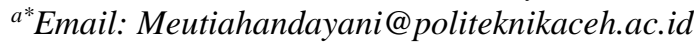

\begin{abstract}
Abstrak
Penelitian ini bertujuan untuk mengetahui peran Bank Indonesia dalam menjaga stabilitas sistem keuangan di tengah pandemi Covid 19, Untuk mengetahui Apakah selama pandemic Covid-19 memaksa Bank Indonesia untuk lebih aktif dalam menjaga stabilitas sistem keuangan di tengah pandemi Covid 19. Penelitian ini menggunakan jenis penelitian literature review. Literature review merupakan suatu penelusuran dan penelitian kepustakaan dengan membaca buku, jurnal, dan terbitan-terbitan lain yang terkait dengan topik penelitian, untuk menghasilkan suatu topik atau isu tertentu, seperti untuk menghasilkan sebuah tulisan ilmiah, seperti skripsi, tesis, dan disertasi. Hasil dari penelitian ini yaitu Bank Indonesia memfungsikan peranannya selaku "lender of resort" dengan memberikan Liquidity support dengan nama Bantuan Likuiditas Bank Indonesia atau BLBI untuk menyelamatkan sistem perbankan, baik untuk keperluan mengatasi kesulitan likuiditas, maupun dalam rangka pelaksanaan Program Penjanjian Pemerintah, Bank Indonesia harus terlibat untuk membantu penyelesaian krisis keuangan yang dihadapi oleh sektor korporasi selaku debitur bank, Bank Indonesia memberikan fasilitas pembiayaan darurat (LOLR), Membentuk institusi yang menjamin deposan kecil (Lembaga Penjamin Simpanan) sebagaipengganti Blanket Guarantee yang tidak best practice. Bank Indonesia berperan aktif dalam persiapan pendirian LPS, Membentuk wadah terkoordinasi terkait dengan stabilitas system keuangan baik secara internal dan eksternal.
\end{abstract}

Kata kunci : Bank Indonesia, stabilitas keuangan, pandemic Covid 19

\begin{abstract}
This study aims to determine the role of Bank Indonesia in maintaining financial system stability in the midst of the Covid 19 pandemic, to find out whether during the Covid-19 pandemic forced Bank Indonesia to be more active in maintaining financial system stability in the midst of the Covid 19 pandemic. This study uses a type of literature research. reviews. Literature review is a literature search and research by reading books, journals, and other publications related to the research topic, to produce a particular topic or issue, such as to produce a scientific paper, such as theses, theses, and dissertations. The results of this study are that Bank Indonesia functions its role as "lender of resort" by providing Liquidity support under the name Bank Indonesia Liquidity Assistance or BLBI to save the banking system, both for the purpose of overcoming liquidity difficulties, as well as in the context of implementing the Government Agreement Program, Bank Indonesia must involved in helping to resolve the financial crisis faced by the corporate sector as bank debtors, Bank Indonesia provided emergency financing facilities (LOLR), Established an institution that guarantees small depositors (Deposit Guarantee Institution) as a substitute for the Blanket Guarantee which is not best practice. Bank Indonesia plays an active role in the preparation for the establishment of the IDIC, Establishing a coordinated forum related to financial system stability both internally and externally.
\end{abstract}

Key Words:Bank Indonesia, financial stability, Covid 19 pandemic 


\section{PENDAHULUAN}

Periode akhir 2019 Indonesia digemparkan dengan hadirnya penyebaran virus Covid19 atau disebut juga dengan virus corona. Hadirnya penyebaran virus Covid-19 menyebabkan berbagai aspek kenegaraan, sosial dan ekonomi mengalami penurunan drastis. Sistem keuangan negara terombang ambing dan mengalami ketidakstabilan. Virus Covid-19 masih termasuk kedalam genom virus SARS yang sempat menyebar dan juga ikut menggegerkan dunia pada waktu sebelumnya.

Coronavirus Disease ini mengingatkan pada kejadian 17 tahun yang lalu, di mana wabah Severe Acute Respiratory Syndrome (SARS) muncul pertama kali di China.Seperti SARS, virus COVID-19 diduga setelah virus masuk ke dalam sel, genom RNA virus akan dikeluarkan ke sitoplasma sel dan menjadi dua polyprotein dan protein struktural (Suni, 2020). Kemudian genom virus akan bereplikasi dan Glikoprotein pada selubung virus yang baru terbentuk masuk ke dalam membrane reticulum endoplasma (Susilo dkk, 2020: 47) Penderita Covid 19 mengalami gejala seperti: gangguan pernafasan, demam, batuk, dan lainnya, dan pada kasus tertentu, corona virus dapat menyebabkan terjadinya kematian bagi orang yang terpapar. Dampak pandemic Covid-19 sangat rentan dan berbahaya bagi orang yang memiliki daya tahan tubuh lemah. Maka, sangat penting untuk menjaga sistem pertahanan imum tubuh untuk tetap sehat agar tidak mudah terserang oleh virus corona.

Permasalahan yang terjadi pada sektor ekonomi akibat pandemi covid 19 bukanlah merupakan tanggungjawab pemerintah pusat sepenuhnya, tetapi juga merupakan tanggungjawab beberapa pihak lainnya, seperti: Bank Indonesia. Tugas Bank Indonesia terkait perekonomian yaitu mencapai dan memelihara kestabilan nilai rupiah melalui kestabilan moneter dan pengembangan stabilitas sistem keuangan untuk pembangunan nasional jangka panjang yang berkesinambungan (Sari:2015). Harapan besar diletakkan pada Bank Sentral pada saat terjadinya ketidakseimbangan atau masalah dalam sektor keuangan mengingat Bank Sentral memiliki wewenang khusus dalam mengatur keuangan dan menjaga kestabilan ekonomi.

Menurut Bank Indonesia dalam Lintangsari,dkk (2018:15) menjelaskan bahwa stabilitas sistem keuangan merupakan suatu aktifitas yang dilakukan dengan meneliti faktorfaktor penyebab dari instabilitas pada sektor keuangan. Selaku otoritas moneter Bank Indonesia memiliki tugas untuk menjaga stabilitas dari sistem keuangan. Walaupun selama pandemi Covid-19 terjadinya penurunan dalam sistem keuangan. Namun, hal ini menjadi tantangan bagi Bank Indonesia untuk menetapkan strategi yang tepat untuk tetap menjaga kestabilan sistem keuangan di Indoesia.

Penyebaran Covid-19 memberi tekanan yang cukup kuat dalam sistem keuangan, sehingga diperlukan tindakan khsusus untuk mengatasi dan menjaga kestabilan sektor keuangan untuk tetap terjaga (Hanoatobun, 2020). Sistem keuangan sangat penting untuk dijaga dan menjadi perhatian tidak hanya bagi pemerintah atau lembaga keuangan saja. Akan tetapi, masyarakat juga harus ikut andil untuk terus mendukung kestabilan dan peningkatan sektor keuangan agar dapat menciptakan hidup yang merata dan sejahtera dalam suatu negara. Penurunan stabilitas sistem keuangan selama Covid-19 diikuti dengan meningkatnya resiko dipasar keuangan global. 
Berdasarkan pada latar belakang masalah di atas, maka penelitian ini akan meneliti lebih dalam dari fenomena masalah yang ada. Penelitian ini bertujuan untuk menganalisis peran Bank indonesia dalam menjaga kestabilan keuangan dan keaktifan Bank Indonesia dalam menjaga satabilitas keuangan di masa pandemi covid 19.

\section{KERANGKA KONSEPTUAL Peran}

Menurut Soerjono Soekanto (2002:243), menjelaskan peran merupakan hak dan kewajiban yang dilaksanakan oleh seseorang disebut juga dengan aspek dinamis dar kedudukan atau setatus seseorang, jika pelaksanaan kewajiban dan hak nya sesuai maka dia dikatakan telah menjalankan atau melaksanakan suatu peranansetiap orang memiliki berbagai karakteristik dalam melaksanakan tugas atau perananya dalam suatu organisasi, berdasarkan ketentuan kewajiban atau tanggung jawab yang telah diberikan oleh organisasi tersebut. Peran yang dimainkan/diperankan pimpinan tingkat atas, menengah maupun bawah akan mempunyai peran yang sama (Lantaeda: 2017). Terdapat tiga komponen dari istilah kata peran yaitu sebagai berikut: (Sutarto: 2009:).

1. Konsepsi peran, yaitu: Rasa percaya dari seseorang terhad sesuatu yang dilakukan.

2. Harapan peran, yaitu: harapan dari salah satu pihak lain kepada pihak yang satunya terhadap sesuatu hal dalam bertindak.

3. Pelaksanaan peran, yaitu: seseorang yang menunjukkan prilaku sesungguhnya dalam melakukan sesuatu hal atau bertindak. Jika dari ketiga komponen tersebut memiliki keserasian maka akan adanya kesinanbungan dalam interaksi sosial.

Berdasarkan uraian penjelasan diatas maka dapat diambil kesimpulan bahwasanya peran memiliki makna sebagai suatu julukan atau tuntutan yang ada pada suatu diri seseorang berdasarkan keinginan dari diri sendiri maupun tuntutan dan harapan orang lain pada dirinya. Peran digambarkan suatu unsur fungsi dari prilaku atau aktivitas yang dilakukan dengan tujuan menjalankan tugas maupun tujuan dari perjalanan proses sesuatu hal.

\section{Pandemi Covid 19}

Corona virus adalah virus RNA dengan ukuran partikel 120-160 nm.Virus ini utamanya menginfeksi hewan, termasuk di antaranya adalah kelelawar dan unta. Sebelum terjadinya wabah COVID-19, ada 6 jenis coronavirus yang dapat menginfeksi manusia, yaitu alphacoronavirus 229E, alphacoronavirus NL63, betacoronavirus OC43, betacoronavirus HKU1, Severe Acute Respiratory Illness Coronavirus (SARS-CoV), dan Middle East Respiratory Syndrome Coronavirus (MERS-CoV).14 Coronavirus yang menjadi etiologi COVID-19 termasuk dalam genus betacoronavirus. Hasil analisis filogenetik menunjukkan bahwa virus ini masuk dalam subgenus yang sama dengan coronavirus yang menyebabkan wabah Severe Acute Respiratory Illness (SARS) pada 2002-2004 silam, yaitu Sarbecovirus.15 Atas dasar ini, International Committee on Taxonomy of Viruses mengajukan nama SARS-CoV-2. (Susilo, 2020). "Virus Corona atau biasa disebut dengan Covid-19 adalah sebuah keluarga virus yag ditemukan pada manusia” (Anggita,dkk :2020). 
Menurut WHO (2020) berdasarkan panduan Surveilans Global, "definisi Covid-19 dapat diklasifikasikan menjadi tiga bagian yakni: (1) kasus terduga atau suspect case, (2) kasus probable atau probable case, dan (3) kasus terkonfirmasi atau pasien yang sudah terbukti positif melalui tes laboratorium"."’Virus ini sudah mewabah di Wuhan, China pada bulan Desember 2019. Lalu pada awal Januari ini WHO sudah mengidentifikasikan virus tersebut sebagai Novel Coronavirus atau 2019-nCoV kemudian pada Februari WHO mengumumkan nama resmi virus ini adalah COVID-19 (KEMKES,2020).

Kesimpulan yang dapat kita ambil yaitu virus Covid-19 merupakan sejenis virus berbahaya yang penyebarannya dimulai dari Wuhan China. Virus ini mampu berkembang dengan sangat cepat dan memberikan efek yang dapat terlihat secara langsung bagi yang terinfeksi.Virus Covid-19 atau disebut juga dengan Corona dapat dikurangi penyebarannya dengan mengurangi kontak langsung dari para penderita, atau menjaga jarak dengan siapa saja yang sudah melakukan kontak fisik langsung pada lingkungan umum. Pandemi Covid19 akan terus menyebar apabila tanpa rasa peduli dari pihak-pihak yang menganggap remeh penyebaran virus ini dengan tidak mematuhi protokol kesehatan yang telah ditentukan oleh departemen kesehatan.

Sebagaimana kita ketahui Covid-19 merupakan sekelompok virus yang berbahaya yang menyerang sistem pernapasan secara ganas dalam waktu singkat dan menyebabkan akibat fatal apabila tidak segera ditangani, ditambah dengan penyebaran yang sangat mudah dan cepat. Virus ini akan sangat berbahaya bagi lansia dan anak-anak balita dengan sistem imum tubuh yang sangat lemah. Dampak negatif dari virus ini tidak hanya dari segi kesehatan. Namun salah satu aspek terbesar dari dampak negatif virus ini adalah melemahnya sistem ekonomi di seluruh penjuru dunia (Br Karo: 2020).

\section{Bank Indonesia}

BI berawal dari De Javasche Bank NV (DJB) yang didirikan oleh pemerintah hindia Belanda pada tanggal 24 Januari 1827. Pada masa itu, DJB berperan menjalankan fungsi beberapa bagian dari fungsi Bank Sentral lainnya dan juga melaksanakan beberapa kegiatan Bank Umum. Hak oktroi diberikan oleh pemerintah Belanda kepada DJB, yaitu hak untuk mengedarkan dan mencetak uang Gulden Belanda sebagaimana tugas dari Bank Umum.

Sadar akan kelemahan peran ganda yang dimainkan oleh BI yaitu kurang sehatnya perkembangan moneter bagi perekonomian, maka pemerintah pada tahun 1968 dikeluarkan UU No. 13 Tahun 1968 Tentang Bank Indonesia. Hadirnya Undang-ndang ini bertujuan untuk dapat menghilangkan serta menghapus perang yang dimiliki oleh Bank Indonesia untuk juga memiliki peran yang ada pada Bank Komersial. Namun, BI ttetap menjading banker dar bank lainnya, tempat menampung keuagna dari pemerintah, dan sebagai penyimpan dana pembangunan negara. Di samping itu, UU ini tetap mempertahankan tugas dan fungsi DM. Tugas pokok BI sebagai agen pembangunan terlihat pada tugas pokoknya, yaitu:

1. mengatur, menjaga, dan memelihara stabilitas nilai Rupiah,

2. mendorong kelancaran produksi dan pembangunan,

3. memperluas kesempatan kerja guna meningkatkan taraf hidup masyarakat. 
Kesimpulan yang dapat diambil bahwa Bank Indonesia merupakan bank induk ataubank pusat di Indonesia yang memiliki peran penting untuk mengontrol atau mengelola beberapa perihal penting yang berkaitan dengan sistem perbankan dan perekonomian di Indonesia. Salahsatunya seperti menjaga kestabilan sektor keuangan, melakukan unsaha untuk dapat mendorong kelancaran dalam prooduk dan pembangunan di Indonesia, dan beberapa tugas lainnya.

\section{Stabilitas Sistem Keuangan}

Sektor perbankan masih mendominasi sistem keuangan diIndonesia . hal tersebut memperlihatkan bahwa sektor perbankan memberikan dampak yang cukup besar dalam sistem keuangan .terlihat bahwa sektor keuangan sangat bergantung pada sektor perbankan. Ukuran atau besarnya sebuah bank sanagt berpengaruh bagi dunia perbankan (Hidayat:2019)

Berdasarkan PBI No 16/11/PBI/2014 disebutkan bahwa ada beberapa faktor yang menyebabkan gangguan dalam stabilitas sistem keuangan. Salah satu penyebabanya yaitu adanya bak yang berukuran cukup besar.Bank yang ukuran atau sizenya cukup besar atau lumayan besar akan memberikan pengaruh yang lebih besar dan kuat terhadap kestabilan sistem keuangan. Bank dengan size atau ukuran yang besar memperlihatkan bahwa bank tersebut memiliki intenisitas kinerja yang tinggi. Semakin banyak jasa yang ditawarkan dan diberikan oleh pihak bank akan memberikan keuntungan yang besar bagi pihak bank tersebutsecara bersamaan bank juga mempengaruhi kenikan pasar keuangan. Penyedia dana yang besar dibutuhkan oleh pihak bank dalam memberikan jasa keuangan yang cukup banyak. Penyedia dana yang besar sangat rentan terhadap informasi asimetris yang dapat menurunkan tingkat kepercayaan dan dapat berakibat pada terjadinya prosikalitasbank besar menjadi pusat krisis utama dari berbagai faktor gangguan yang ada (Harun et al, 2015).

Kesimpulannya yaitu stabilitas sektor keuangan sangat dipengaruhi oleh sistem perbankan. Pada sektor perbankan salah satu jenis usaha yang cukup berpengaruhi yaitu lembaga bank. Bank yang besar memberikan dampak yang besar dalam sektor yang besar. Semakin besar bank yang ada akan lebih berpengaruh memberikan gangguan pada stabilitas sektor keuangan. Bank yang besar memang meiliki keunggulan untuk bertahan disaat krisis ekonomi yang terjadi. Namun, tetap adanya resiko yang besar yang harus dihadapi

\section{METODE PENELITIAN}

\section{Jenis Penelitian}

Penelitian ini menggunakan jenis penelitian literature review. Literature review merupakan suatu penelusuran dan penelitian kepustakaan dengan membaca buku, jurnal, dan terbitan-terbitan lain yang terkait dengan topik penelitian, untuk menghasilkan suatu topik atau isu tertentu, seperti untuk menghasilkan sebuah tulisan ilmiah, seperti skripsi, tesis, dan disertasi . Rangkuman menyeluruh dalam bentuk literature review mengenai perubahan fisiologis dan psikologis pada lansia. Protokol dan evaluasi dari literature review dengan menggunakan PRISMA checklitst untuk menentukan penyeleksian studi yang telah ditemukan dan disesuaikan dengan tujuan dari literature review.

Literature review dianggap tepat dan mampu menghasilkan tercapainya hasil 
penelitian yang konkret dan valid. Literature review diperkirakan akan mudah untuk mencari dan mengumpulkan bahan-bahan yang diperlukan dalam melakukan penelitia ini. PRISMA checklist merupakan protokol atau evaluasi yang dari metode literature review yang akan dilakukan untuk menyeleksi setiap hasil studi dari penelitian sebelumnya.

Metode pengumpulan data adalah studi pustaka. Jenis data yang digunakan dalam penelitian ini adalah data sekunder yaitu data yang diperoleh dari Paper dari Jurnal Ilmiah, Paper dari Conference (Proceedings), Tesis dan Disertasi, Report (Laporan) dari Organisasi yang Terpercaya dan jurnal-jurnal penelitian terdahulu yang dilakukan.

\section{Pemilihan Data}

1. Pemilihan artikel pada penelitian literatur review ini menggunakan mnemonic Populasi, Conteks and Concept (PCC) sebagai berikut:

a. Population

Populasi pada penelitian ini adalah Peran Bank Indonesia Dalam Menjaga Stabilitas Sistem Keuangan Di Tengah Pandemi Covid 19

b. Context

1) Peran Bank Indonesia

2) Stabilitas Sistem Keuangan

3) Peran Bank Indonesia Dalam Menjaga Stabilitas Sistem Keuangan Di Tengah Pandemi Covid 19

2. Mekanisme pencarian artikel literatur review

Metode yang digunakan dalam pemelihan artikel adalah penelusuran literatur melalui database online yaitu Google Cendekia danGoogle. Penulis membuka website https://cendekia.google.co.id/, kemudian menuliskan kata kunci "Peran Bank Indonesia" DAN"Stabilitas Sistem Keuangan Di Tengah Pandemi Covid 19" dari database online Google Cendekia. Artikel yang didapat dipilih berdasarkan kriteria tahun penulisan sumber tersebut.

\section{Teknik analisis data}

Data-data yang sudah diperoleh kemudian dianalisis dengan metode analisis deskriptif. Metode analisis deskriptif dilakukan dengan cara mendeskripsikan fakta-fakta yang kemudian disusul dengan analisis, tidak semata-mata menguraikan, melainkan juga memberikan pemahaman dan penjelasan secukupnya. Data yang diperoleh dikompulasi, dianalisis, dan disimpulkan sehingga mendapatkan kesimpulan mengenai studi literature.

kegiatan analisis dari data dengan melalui tiga aspek pertimbangkan dan memilah setiap hasil analisis yang dihasilkan yaitu dengan kelompok tingkat relevan yang terdiri dari tingkat paling relevan, relevan dan cukup relevan. Analisis lainnya dilakukan dengan menganalisis penelitian-penelitian terdahulu lainnya yang relevan dengan penelitian ini dengan ketentuan batas tahun yang diambil agar tidak terjadinya kadarluarsa atau ketertinggalan dalam perkembangan ilmu yang ada. Kegiatan analisis akan dilakuka secara kritis dan dilakukan secara terus menerus sampai dapat menjawab hasil penelitian atau tujuan dari dilakukannya penelitian ini. 


\section{HASIL DAN PEMBAHASAN}

Pandemi Covid-19 menyebabkan stabilitas sistem keuangan mengalami penurunan. Ketidakseimbangan kas negara dan nilai rupiah menyebabkan banyaknya terjadi kekacauan dalam sistem keuangan Indonesia. Berdasarkan hasil penelitian dari Lintangsari,dkk (2018) menghasilkan bahwa salah satu faktor yang juga berpengaruh pada tingkat kestabilan sistem keuangan yaitu kegiatan transaksi e-money karena menyebabkan nilai suku bunga tidak stabil. Hal ini menyebabkan BI harus menerapkan kebijakan agar tidak terjadinya penurunan tingkat suku bunga secara terus menerus. Misalnya seperti penggunaan kartu kredit memberikan resiko bagi perbankan untuk mengalami kerugian dikarenakan setoran yang harusnya dilunasi tidak dibayarkan atau disetor oleh masyarakat yang menggunakan kartu kredit.

Bank Indonesia mengamban peran penting untuk menjaga kestabilan sistem keungan di Indonesia. Adanya lembaga perbankan Bank Indonesia dapat menjaga dan meningkatkan perekonomian Indonesia terutama dimasa pandemi Covid-19. Bank Indonesia merupakan salah satu lembaga yang juga menjadi harapan untuk mewujudkan Indonesia dengan perekonomian yang maju. Berdasarkan hukum bank sentral terbukti memiliki derajat relative yang dilalui berdasarkan pengukuran ari waktu ke waktu. Konsenkuesi yang besar berdampak bagi bank sentral selama hadirnya pandemi Covid-19. Bank Indonesia terpaksa harus melakukan penyesuaian akibat dari dampak Covid-19 yang mempengaruhi sistem keuangan nasional. Berdasarkan hasil penelitian Isyunanda (2020) dari menjelaskan bahwa bank sentral menjadi relativitas suatu konsekuensi dalam makro ekonomi. Pertimbangan yang dilakukan oleh bank sentral dalam mengantisipasi dampak pandemi Covid terhadap kestabila sektor keuangan harus memperhatikan beberapa aspek yang menyebabkan tidak boleh hilangnya institusional, fungsional, dan personal autonomy dan merupakan bagian dari indipendensi bank sentral. Pengelolaan siklus ekonomi akan sulit untuk dilaksanakan jika indipendensi tidak terukur dengan baik.

BI yang berperan dalam menjaga kestabilan yang memberikan pertumbuhan lebih lanjut, harus menghadapi berbagai resiko yang cukup besar dengan mandate-mandat atau aturan yang telah ditetapkan. Bank Indonesia atau disebut juga sebagai Bank Sentral memang menjadi andalan bagi pemerintah dalam mengawasi dan antisipasi terhadap gangguan dalam kestabilan ekonomi terutama yang menyangkut dengan kestabilan sektor keuangan. Pandemi Covid-19 yang menyebabkan banyanyak korban jiwa mempengaruhi dinamika ekonomi. Pengeluaran dana tidak dapat dihindari dalam proses antisipasi dan mencegah semakin buruknya dampak penyebaran pandemic Covid-19 bagi masyarakat Indonesia. Bank sentral tetap harus mampu mengelola siklus ekonomi berdasarkan prinsip Keynesianism saat keadaan kembali pulih demi terwujudnya kestabilan.

Pengalaman Dalam Penyelamatan Sistem Keuangan / Perbankan Nasional di Masa Krisis Krisis keuangan dan perbankan yang terjadi tahun 1997-1998 telah memberikan pelajaran yang sangat berharga mengenai pentingnya penciptaan suatu kerangka stabilitas sistem keuangan dimana stabilitas sistem keuangan merupakan suatu rangkaian proses dan kegiatan yang diawali dengan pemantauan (surveillance) dan identifikasi kemungkinan timbulnya suatu krisis, sampai dengan pencegahan krisis tersebut terjadi. Aspek pemantauan dan identifikasi krisis merupakan salah satu pilar penting dalam menjaga stabilitas sistem 
keuangan karena langkah preventif dan antisipasif dipandang sebagai langkah yang lebih murah daripada penyelesaian krisis (crisis resolution). Menjaga stabilitas keuangan merupakan salah satu fungsi pokok dari Bank sentral modern, yang tidak kalah pentingnya dari memelihara stabilitas moneter. Stabilitas keuangan bergantung pada lima elemen terkait yakni :

1. Lingkungan makro-ekonomi yang stabil;

2. Lembaga finansial yang dikelola baik;

3. Pasar finansial yang efisien;

4. Kerangka pengawasan prudensial yang sehat;

5. Sistem pembayaran yang aman dan handal.

Pengalaman krisis tersebut bagi Bank Indonesia dapat dijadikan suatu pelajaran penting bahwa tugas bank sentral sebagai penjaga stabilitas moneter (otoritas moneter) tidaklah cukup tanpa dukungan stabilitas sistem keuangan yang sehat. Gejolak dalam lembaga keuangan khususnya bank, merupakan salah satu sumber instabilitas. Oleh karena itu, krisis perbankan harus dicegah atau ditangani untuk menghindarkan gangguan terhadap sistem pembayaran dan arus kredit dalam perekonomian. Terkait dengan hal tersebut, upaya membangun sistem keuangan yang stabil memerlukan perangkat aturan hukum (legal framework) yang mampu menjadi landasan bagi penyelenggaraan fungsi bank sentral secara utuh. Sebagaimana telah dipahami bahwa dalam Legal framework sistem keuangan dan perbankan nasional yang berlaku pada masa terjadinya krisis, bank sentral yang pada waktu itu merupakan bagian dari otoritas perbankan tidak dilengkapi dengan perangkat hukum yang memadai ketika harus mengambil tindakan darurat guna mengatasi systemic risk di sektor perbankan yang hampir-hampir saja melumpuhkan sistem perbankan nasional. Upaya mengatasi krisis perbankan pada masa itu dianggap perlu menggunakan dua pendekatan yaitu :

1. Perlunya mem-back-up sistem perbankan nasional agar tidak collaps

2. Membantu penyelesaian krisis keuangan yang dihadapi sektor korporasi untuk memulihkan sektor perbankan dan perekonomian nasional.

Strategi Bank Indonesia dalam mengatasi Krisis Keuangan dan Perbankan Nasional saat ini antara lain :

1. Bank Indonesia memfungsikan peranannya selaku "lender of resort " dengan memberikan Liquidity support dengan nama Bantuan Likuiditas Bank Indonesia atau BLBI untuk menyelamatkan sistem perbankan, baik untuk keperluan mengatasi kesulitan likuiditas, maupun dalam rangka pelaksanaan Program Penjanjian Pemerintah.

2. Bank Indonesia harus terlibat untuk membantu penyelesaian krisis keuangan yang dihadapi oleh sektor korporasi selaku debitur bank.

3. Bank Indonesia memberikan fasilitas pembiayaan darurat (LOLR).

4. Membentuk institusi yang menjamin deposan kecil (Lembaga Penjamin Simpanan) sebagaipengganti Blanket Guarantee yang tidak best practice. Bank Indonesia berperan aktif dalam persiapan pendirian LPS.

5. Membentuk wadah terkoordinasi terkait dengan stabilitas system keuangan baik secara internal dan eksternal. 


\section{KESIMPULAN, KETERBATASAN DAN SARAN}

Bank Indonesia memiliki peran penting dalam menjaga kestabilan sistem keungan di Indonesia dan meningkatkan perekonomian Indonesia terutama selama masa Pandemi Covid 19. Selain itu, Bank Indonesia aktif dalam mengatasi Krisis Keuangan dan Perbankan Nasional saat ini sebagai peranannya selaku "lender of resort " dengan memberikan Liquidity support dengan nama Bantuan Likuiditas Bank Indonesia atau BLBI.

Keterbatasan penelitain ini adalah hanya sebatas dari sudut pemikiran peran dan keaktifan Bank Indonesia dalam menjaga stabilitas keuangan di masa PandemiCovid 19 saat ini saja. Disarankan untuk peneliti selanjuntya untuk menambahkan elemen-elemen lainnya sebagai pengukuran menjaga stabilitas keuangan saat yang akan datang.

\section{DAFTAR PUSTAKA}

Br Karo, Marni. 2020.Perilaku Hidup Bersih dan Sehat (PHBS) Strategi Pencegahan Penyebaran Virus Covid-19.Prosiding Seminar Nasional Hardiknas.

Hanoatubun, Silpa .2020. Dampak Covid -19 Terhadap Perekonomian Indonesia.Jurnal EduPsyCouns. (2)1.

Hidayat, Maulana. I Made dana.2019. Pengaruh Intellectual Capital Terhadap Kinerja Keuangan Perusahaan Sektor Pertambangan Di Bursa Efek Indonesia. E-Jurnal Manajemen Universitas Udayana. 9 (1).

Isyunanda, Kristianus Pramudito. 2020. Bank Sentral dan Pnademi Covid-19: Quo Vadis?. Jurnal Mimbar Hukum. 2(3).

Kementerian Kesehatan (KEMKES). 2020. Informasi tentang virus Corona. Diakses pada

13 Oktober 2021 dari https://promkes.kemkes.go.id/informasi-tentang-virus-coronanovel-coronavirus.

Lantaeda, Syaron Brigette, dkk. 2017. Peran Badan Perencanaan Pembangunan Daerah Dalam Penyusunan Rpjmd Kota Tomohon. Jurnal Jurnal Administrasi Publik. 4 (48).

Lintangsari, Nastiti Ninda, Nisaulfathona Hidayati, Yeni Purnamasari, dan Hilda Carolina. 2018. Analisis Pengaruh Instrumen Pembayaran non Tunai Terhadp Stabilitas Sistem Keuangan di Indonesia. 1 (1): 1-17.

Peraturan Bank Indonesia Nomor 16/11/PBI/2014.2014 Tentang Pengaturan dan

Sutarto. 2009. Dasar-Dasar Organisasi. Yogyakarta: UGM press.

Sari, Dian Indah. 2015. Analisis Terhadap Peranan Dan Strategi Bank Indonesia Serta Pemerintah Dalam Menjaga Stabilitas Sistem Keuangan Di Indonesia. Jurnal Moneter. 2(1)

Suni, Nur Sholikah Putri.2020. Kesiapsiagaan Indonesia Menghadapi Potensi Penyebaran Corona Virus Disease.Jurnal Kesejahteraan Sosial. 12 (3).

Susilo, Aditya.2020. Coronavirus Disease 2019; Tinjauan Literatur Terkini.Jurnal Penyakit Dalam Indonesia.

Wold Health Organization. (2020). Naming the coronnavirus disease (COVID-19) and the vrus causes it. Diakses pada 13 Oktober 2021 dari

https://openwho.org/channels/covid-19 
Agus, Yus Amri. 2011. Pemahaman Aparatur Pemerintah Daerah terhadap PrinsipPrinsip Tata Pemerintahan Yang Baik. Tesis. Universitas Lampung.

Agusti, Restu. 2012. Pengaruh Partisipasi Penyusunan Anggaran terhadap Kinerja Aparatur Pemerintah Daerah dengan Dimoderasi oleh Variabel Desentralisasi dan Budaya Organisasi. Jurnal Ekonomi. 20 (3).

Akbar, Amirul dkk. 2017. Pengaruh Komitmen Organisasional terhadap Kinerja. Jurnal Administrasi Bisnis (JAB). 47 (2).

Anisa Sitompul, Putri Baday. 2014. Implementasi Kebijakan Pengelolaan Keuangan

Daerah pada Bagian Keuangan Sekretariat Daerah Kabupaten Kutai Barat Berdasarkan Peraturan Daerah No. 20 Tahun 2007 Tentang Pokok-Pokok Pengelolaan Keuangan Daerah. Artikel Ejournal.

Arifin, Solikhun. 2012. Pengaruh Partisipasi Penyusunan Anggaran terhadap Kinerja Aparat Pemerintah Daerah: Komitmen Organisasi, Budaya Organisasi, dan Gaya Kepemimpinan sebagai Variabel Moderasi. Skripsi. Universitas Dipenogoro.

Aziz, Nur Jannah Abdi, dkk. 2018. Pengaruh Sistem Pengendalian Intern Pemerintah, Sistem Informasi Manajemen Daerah dan Kualitas Sumber Daya Manusia terhadap Kinerja Manajerial Aparatur Pemerintah Daerah.Jurnal Ekonomi, Bisnis, dan Akuntansi (JEBA).Vol.20, No.4.

Claraini, Chici. 2017. Pengaruh Good Governance, Sistem Pengendalian Intern

Pemerintah dan Gaya Kepemiminan terhadap Kinerja Pemerintah Daerah. JOM Fakultas Ekonomi. 4 (1).

Defitri, Siska Yulia. 2018. Pengaruh Pengelolaan Keuangan Daerah dan Sistem Akuntansi Keuangan Daerah terhadap Kualitas Laporan Keuangan Pemerintah Daerah. Jurnal Benefita. 3 (1): 64-75.

Fidelius. 2013. Analisis Rasio untuk mengukur Kinerja Pengelolaan Keuangan Daerah Kota Manado. Jurnal EMBA. 4 (1).

Ghozali, Imam. 2015. Konsep, Teknik dan Aplikasi Menggunakan Aplikasi

SmartPLS 3.0. Edisi 2. Semarang: Badan Penerbit Universitas Diponegoro.

Hanif. 2012. Urgensi Sistem Pengendalian Intern Bagi Instansi Pemerintah. ASAS. 4 (2).

Herawati, Tuti. 2014. Pengaruh Sistem Pengendalian Intern terhadap Kualitas Laporan Keuangan. STAR-Study Accounting Research. 11 (1).

Hindriani, Nuning dkk. 2012. Sistem Pengendalian Intern Pemerintah (SPIP) Dalam Perencanaan dan Pelaksanaan Anggaran di Daerah.Wacana. 15 (3).

Jalius, M. Fajri. 2017. Pengaruh Sistem Pengendalian Intern, Pengelolaan Keuangan

Daerah Dan Komitmen Organisasi terhadap Penerapan Good Government Governance. JOM Fekon. 4 (2).

Jenedi, Antonio. 2015. Studi Tentang Kinerja Aparatur Pemerintah Di Kantor Badan Perencanaan Pembangunan Daerah Kabupaten Kutai Barat. eJournal Administrasi Negara. 3 (3): 700-713.

Laporan Kinerja Instansi Pemerintah Kota Langsa Tahun 2018

Mahesthi, Maruti Giri. 2017. Pengaruh Implementasi Sistem Pengendalian Intern Pemerintah dan Tindak Lanjut Hasil Pemeriksaan Terhadap Penerapan Good 
Governance dan Dampaknya Terhadap Akuntabilitas Kinerja Instansi Pemerintah. Jurnal Ekonomi dan Bisnis Terapan. 13 (2).

Mukhlis, Ahmad. 2015. Implementasi Prinsip Good Governance di Pemerintahan Desa.

Skripsi. Universitas Muhamadiya Surakarta.

Pangestika, Fierda. 2016. Pengaruh Pengendalian Internal, Good Governance, Komitmen

Organisasi terhadap Kinerja Pegawai Bidang Keuangan Pemerintah Daerah

Kabupaten Temanggung. Skripsi. Universitas Negeri Yogyakarta.

Peraturan Pemerintah Nomor 58 Tahun 2005 Tentang Pengelolaan Keuangan Daerah.

Peraturan Pemerintah Nomor 60 Tahun 2008 Tentang Sistem Pengendalian Intern Pemerintah (SPIP).

Purnami, Rahayu S. 2013. Pengaruh Kepuasan Kerja Dan Komitmen Organisasional

Terhadap Kewarganegaraan Organisasional Serta Implikasinya Terhadap Kinerja

Pegawai Administrasi Politeknik Komputer Niaga Lpkia Bandung. Skripsi.

Universitas Pendidikan Indonesia.

Ruspina, Depi Oktia. 2013. Pengaruh Kinerja Aparatur Pemerintah Daerah, Pengelolaan

Keuangan Daerah, Sistem Pengendalian Internal Pemerintah (SPIP) terhadap

Penerapan Good Governance. Skripsi. Universitas Negeri Padang.

Sagita, Amelia Dara, dkk. 2018. Optimalisasi Pengelolaan Keuangan Berbasis Tata

Kelola Pemerintahan Yang Baik dan Dampaknya Terhadap Kinerja Pemerintah

Daerah. Jurnal Magister Manajemen. 2 (1).

Sari, Finda Dwita, dkk. 2017. Determinan Implementasi Good Governance serta Implikasinya pada Akuntabilitas Keuangan Daerah. Jurnal Akuntansi dan Keungan Universitas Jambi.

Sari, Weni Nirmala. 2017. Pengaruh Kinerja Aparatur Pemerintah Daerah, Pengelolaan

Keuangan Daerah, Sistem Pengendalian Intern Pemerintah (SPIP), dan Komitmen

Organisasi terhadap Good Governance. JOM Fakultas Ekonomi. 4 (1).

Siwambudi, I Gusti Ngurah, dkk. 2017. Komitmen Organisasi Sebagai Pemoderasi

Pengaruh Kompetensi SDM dan Sistem Pengendalian Intern Pada Kualitas Laporan

Keuangan. E-Jurnal Ekonomi dan Bisnis Universitas Udayana. 6 (1).

Sugiyono. 2015. Metode Penelitian Kuantitatif, Kualitatif dan R\&D. Bandung: Alfabeta.

Syafrion, Fanda Yovano. 2015. Pengaruh Sistem Pengendalian Intern, Pengelolaan Keuangan Daerah, Komitmen Organisasi dan Budaya Organisasi terhadap Penerapan Good Governance. JOM Fakultas Ekonomi. 2(2).

Taufik, Taufeni dan Dian Kemala. 2013. Pengaruh Pemahaman Prinsip-prinsip Good Governance, Pengendalian Intern dan Komitmen Organisasi terhadap Kinerja Sektor Publik. Pekbis Jurnal. 5 (1).

Tomuka, Shinta. 2013. Penerapan Prinsip-prinsip Good Governance dalam Pelayanan Publik di Kecamatan Girian Kota Bitung. Jurnal Eksekutif. 2 (1).

Trisno, Andhika dkk. 2017.Penerapan Prinsip-Prinsip Good Governence dalam Pelayanan Publik di Kecamatan Wanea Kota Manado. Jurnal Eksekutif. 1 (1).

Wiratno, Adi, dkk. 2013. Pengaruh Budaya Organisasi, Gaya Kepemimpinan, Komitmen

Organisasi dan Pengendalian Intern terhadap Penerapan Good Governance serta 
Implikasinya pada Kinerja. Jurnal Pembangunan Fakultas Ekonomi dan Bisnis. Universitas Jenderal Soedirman. 